\title{
MOLECULAR SYSTEMATIC ANALYSIS OF TRANS-EQUATORIAL INTERCHANGE: TESTING THE HISTORICAL BIOGEOGRAPHY OF NORTHERN AND SOUTHERN HEMISPHERE INTERTIDAL LIMPETS
}

WRAY*, Charles G., Department of Integrative Biology, University of California, Berkeley, CA 94720, U.S.A.; CUNNINGHAM, Clifford, Department of Zoology, Duke University, Box 90325, Durham NC 27708-0325, U.S.A.; LINDBERG, David R., Department of Integrative Biology, University of California, Berkeley, CA 94720, U.S.A.

Numerous intertidal, molluscan genera of temperate faunal provinces exhibit anti-tropical distributions. The fossil record suggests that in some genera these distributional patterns are the result of successful dispersal across warm equatorial waters. Molecular systematic analyses of extant members of Discurria/Scurria (Acmaeidae, Gastropoda) and Fissurella (s.s.) (Fissurellidae, Gastropoda) are used to test paleontologic evidence which suggests that species in these genera have dispersed across the tropics. Numerous species of Scurria first appear in the Pliocene of Chile. The first members of the sister genus Discurria appear in the Pliocene of southern California; however, it is not until the Pleistocene that Discurria becomes a ubiquitous member of the California rocky intertidal fauna. The genus Fissurella also first appears in the Pliocene of Chile, but the single northern Pacific species, Fissurella volcano, does not appear until the early Pleistocene in California. Analyses of these genera are used to assess whether a clear source, sister-taxon can be identified for the immigrant taxon(a), and whether the phylogenies and the fossil record are congruent. We use mtDNA sequence data from the 16S rDNA and the Cytochrome Oxidase I genes for the relevant taxa in these genera to reconstruct phylogenetic trees.

Phylogenetic hypotheses are placed in temporally scaled framework which is used to test competing hypotheses of vicariance and dispersal. 